\title{
Picking out the plum jobs: feeding ecology of curlews Numenius arquata in a Baltic Sea wind flat
}

\author{
Heike Rippe, Volker Dierschke* \\ Ernst-Moritz-Arndt-Universität Greifswald, Vogelwarte Hiddensee, D-18565 Kloster, Germany
}

\begin{abstract}
On the German Baltic Sea coast most migrating shorebirds stage in wind flats that are characterized by irregular wind-induced fluctuations of water level. As it had been suggested that large shorebirds cannot fulfil their energetic requirements in wind flats due to the lack of prey organisms large enough to be profitable, we investigated the feeding ecology of curlews Numenius arquata at Hiddensee (July to November 1995). Most prey taken were the largest ragworms Nereis diversicolor present in the sediment ( $>85$ segments), while 2 bivalves contributed $4.2 \%$ (Cerastoderma lamarcki) and $0.8 \%$ (Mya arenaria), respectively. Most curlews foraged in shallow water where we observed the maximum intake rate ( 3.5 prey $\mathrm{min}^{-1}$ ) compared to exposed flats $\left(2.0 \mathrm{prey} \mathrm{min}^{-1}\right)$. This is thought to be the result of highest surface activity and therefore best detectability and accessibility of ragworms in shallow water. Prolonged periods of low foraging activity in late morning and around noon as well as the aggregation at night roosts suggest that curlews do not have problems maintaining their energy budget in the study area. This is explained by their ability to find the few most profitable prey organisms available, even though these occur at low density
\end{abstract}

KEY WORDS: Shorebirds - Numenius arquata - Feeding ecology - Wind flats - Baltic Sea - Nereis diversicolor $\cdot$ Mya arenaria $\cdot$ Cerastoderma lamarcki

\section{INTRODUCTION}

For many coastal shorebirds living along the East Atlantic Flyway in the non-breeding season, the Wadden Sea is an important staging area (Meltofte et al. 1994). Extensive mudflats hold a large spectrum of macrobenthic invertebrates which serve as an excellent food supply for shorebirds and other coastal birds (Beukema et al. 1993, Zwarts \& Wanink 1993). However, the foraging behaviour of birds is strongly constrained by the tides which make food resources inaccessible at high tide and determine activity and, therefore, availability of the macrozoobenthos (Vader 1964, Esselink \& Zwarts 1989). In contrast, coastal habitats at the southern Baltic Sea coast are much less influenced by tides, as fluctuations of water level are mainly induced by wind direction and wind force as

\footnotetext{
- Addressee for correspondence.

E-mail:volker-ifv@t-online.de

well as atmospheric pressure (Brosin 1965). As a result, sand flats show an irregular and unpredictable pattern of emersion and inundation. Due to the low salinity in the Baltic Sea, these so-called wind flats hold an invertebrate fauna much lower in diversity and in part with reduced body size compared to the North Sea (Remane 1940). Nevertheless, many shorebirds use these wind flats as stopover sites during migration (Kube \& Struwe 1994), although feeding conditions are considered to be unfavourable for at least some of the species (Kube 1994). Especially large shorebirds such as curlew Numenius arquata and bar-tailed godwit Limosa lapponica are supposed to suffer from the small size and low profitability of their preferred prey (the ragworm Nereis diversicolor). In theory, this should cause birds to leave the site (godwit) or switch to inland foraging habitats (curlew) in order to match their energetic requirements (Kube 1994).

In contrast to this scenario, a wind flat area off the island of Hiddensee (NE Germany) was observed to hold numbers of curlews throughout the non-breed- 
ing season, which only exceptionally leave the site for other foraging habitats. This implies that the feeding conditions in the Hiddensee wind flat must be sufficient with regard to abundance and availability of prey for curlews. In order to test this hypothesis, data about the macrozoobenthos and the mode of its harvesting by curlews were needed. Besides sampling benthic invertebrates, we studied in which parts of the wind flat area curlews forage (scanning for foraging habitats), which and how many prey they take (examination of pellets/droppings and observation of feeding birds, respectively) and how they allocate their foraging time over the day (scanning for percentages of foraging birds). We aim to show how a shorebird usually living under and potentially adapted to tidal conditions organizes foraging in a non-tidal environment.

\section{STUDY AREA AND METHODS}

As part of the national park 'Vorpommersche Boddenlandschaft', the wind flat area 'Bessinsche Schaar' $\left(54^{\circ} 35^{\prime} \mathrm{N}, 13^{\circ} 09^{\prime} \mathrm{E}\right)$ is situated in the shelter of the islands of Hiddensee and Rügen (Fig. 1). Extending over 180 ha, this sandy study area is smaller than the 2 other wind flats 10 and $15 \mathrm{~km}$ further south (Vierendehlgrund, 1500 ha and Bock, 1500 ha). Together these 3 sites are the most important wetlands for staging shorebirds on the German Baltic Sea coast (Kube 1994, Kube \& Struwe 1994)

Within the studied wind flat, a 9 ha square ranging from $15 \mathrm{~cm}$ below to $10 \mathrm{~cm}$ above mean sea level was divided into 9 plots of 1 ha each and marked with posts (Fig, 1). More than $5 \mathrm{~cm}$ below mean sea level the sediment was covered with aquatic plants (Ruppia maritima/cirrhosa, Potamogeton pectinatus).

Macrozoobenthos. In July and October 1995, in each plot (in August and September 1995 in only 3 plots) 3 samples of macrozoobenthos, taken with a $10 \times 10 \mathrm{~cm}$ corer reaching $20 \mathrm{~cm}$ deep, were sieved through a $0.5 \mathrm{~mm}$ mesh and frozen pending further treatment. Samples were searched for invertebrates under a stereomicroscope. Shell length of bivalves was measured to the nearest $0.5 \mathrm{~mm}$, while ragworms were sorted according to the number of segments. In a sample of the ragworms we also measured relaxed body length for conversion from number of segments (SGM) to worm length (WL):

$$
\begin{gathered}
\log W L=1.899 \log S G M-1.860 \\
\left(R^{2}=0.960, n=366\right)
\end{gathered}
$$

For size classes separately, 2201 ragworms were dried for 48 h at $60^{\circ} \mathrm{C}$ and combusted for $5 \mathrm{~h}$ at $550^{\circ} \mathrm{C}$. Ash-free dry mass (AFDM) for bivalves was calculated

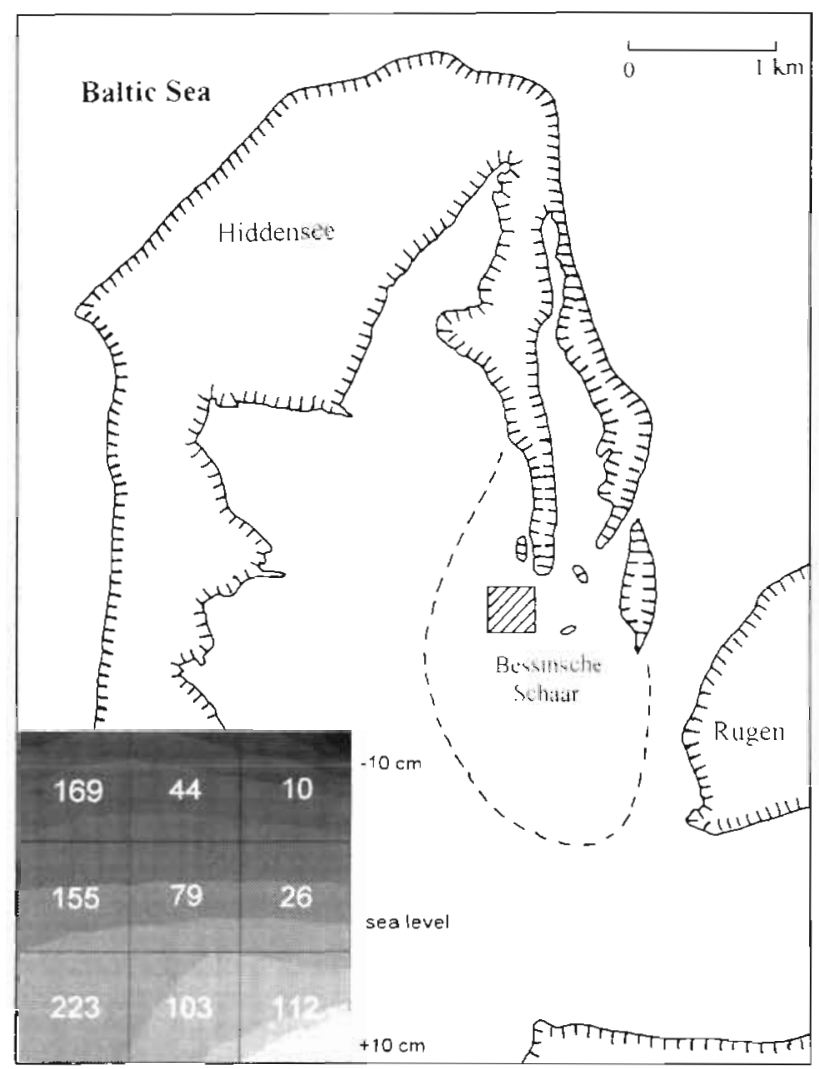

Fig. 1 Map of the study area. ( $\ldots$ ) Outline of wind flat area $_{i}$ (2) study plots. The shaded areas of the inset show the different height of the plots (measuring $100 \times 100 \mathrm{~m}$ ) in relation to mean sea level. In addition, the number of curlews counted during 534 scans from July to October 1995 is given for each plot

according to Zwarts 1991 (adopting formulae of Cerastoderma edule for C. lamarcki).

Feeding behaviour of curlews. Over the whole wind flat area (including parts outside the plots), we differentiated between 5 habitats: dry and wet sand (which could be distinguished by sediment colour), and shallow water $3 \mathrm{~cm}$ deep, up to $9 \mathrm{~cm}$ deep (water reaching the intertarsal joint of curlews) and up to $15 \mathrm{~cm}$ deep (water reaching belly). For male and female curlews foraging in these habitats we observed intake rates by counting swallowing movements during bouts lasting 1 to 7 min (July to November 1995). As bivalves were much easier to identify than ragworms, swallowing movements without determination of prey were considered to be ragworms.

We scanned all curlews foraging in the wind flat area to determine their distribution with regard to the habitats mentioned above, but for practical reasons lumped the 3 to 9 and 9 to $15 \mathrm{~cm}$ habitats for this purpose (354 scans, July to October 1993-95). Unfortunately, the size of exposed parts of the wind flat area in rela- 
tion to the water level remained unknown, but all flats were inundated at $22 \mathrm{~cm}$ above mean sea level while almost all parts were exposed at about $25 \mathrm{~cm}$ below mean sea level. Additional information about choice of foraging habitat was obtained from the number of foraging curlews in the 9 plots counted every 30 min during observation periods of several hours (534 scans on 81 days) from July to October 1995.

As curlews spent most time in inundated habitats (see 'Results'), we could collect only 7 droppings and 8 pellets. These were scanned for prey remains such as ragworm jaws and hinges of bivalve shells, but prey lacking hard and indigestible body parts could not be recorded by this method (in this study only referring to Arenicola marina, which occurs in the study area at very low densities, see below). In order to convert the size of prey remains to body size, jaw length ( $\mathrm{JL}$, in mm; Zwarts \& Esselink 1989) and hinge height ( $\mathrm{HH}$, in mm; Dekinga \& Piersma 1993) were measured in a number of ragworms and bivalves, respectively. The resulting relationships

$$
\begin{aligned}
& \mathrm{SL}=12.581 \mathrm{HH}+1.257\left(\mathrm{R}^{2}=0.880, \mathrm{n}=95\right) \\
& \quad \text { for Mya arenaria, } \\
& \mathrm{SL}=7.224 \mathrm{HH}+2.461\left(\mathrm{R}^{2}=0.878, \mathrm{n}=88\right) \\
& \quad \text { for Cerastoderma lamarcki and } \\
& \mathrm{SGM}=31.905 \ln \mathrm{JL}+86.018\left(\mathrm{R}^{2}=0.977, \mathrm{n}=79\right) \\
& \quad \text { for Nereis diversicolor }
\end{aligned}
$$

allowed us to calculate worm length (SGM, in number of segments) and shell length (SL, in $\mathrm{mm}$ ), respectively. Ragworm jaws larger than those found in the longest worms examined from benthos samples were treated as a '> 85 segments' size class.

A measure of the daily pattern of foraging activity was gained by counting numbers of foraging and nonforaging curlews every 15 or 30 min during several observation periods from 1993 to 1995 (scan sampling; Altmann 1974). For every hour of the day the average percentage of birds foraging $\left(b_{1}\right)$ was calculated. Total foraging time (TFT) of an average curlew during daylight (45 min before sunrise until $45 \mathrm{~min}$ after sunset) was estimated as

$$
\mathrm{TFT}=\sum\left(a, \times b_{i}\right)
$$

with the number of minutes in $1 h\left(a_{i}\right)$. At dawn and dusk, $a_{i}$ is actually less than 60 min because of darkness in part of the hour.

\section{RESULTS}

\section{Occurrence of curlews at Hiddensee}

Except during the breeding season (May to mid June), when only a few birds were present, curlews stayed throughout the year at the wind flats around the island of Hiddensee. In 1994 and 1995, a flock of 60 to 80 birds was observed until late April and from mid July onwards in the 180 ha study area (Fig. 2). In July and August most birds present conducted their postnuptial moult. Fluctuation in numbers occurred due to staging migrants and due to individuals foraging elsewhere and using the site as a night roost only occasionally. During the severe winter $1995 / 96$ with icecovered wind flats, curlews remained for about 6 wk into the cold spell (until early February) before leaving the region. The subsequent numbers during spring and summer 1996 were lower than those observed in the preceding years (Fig, 2).
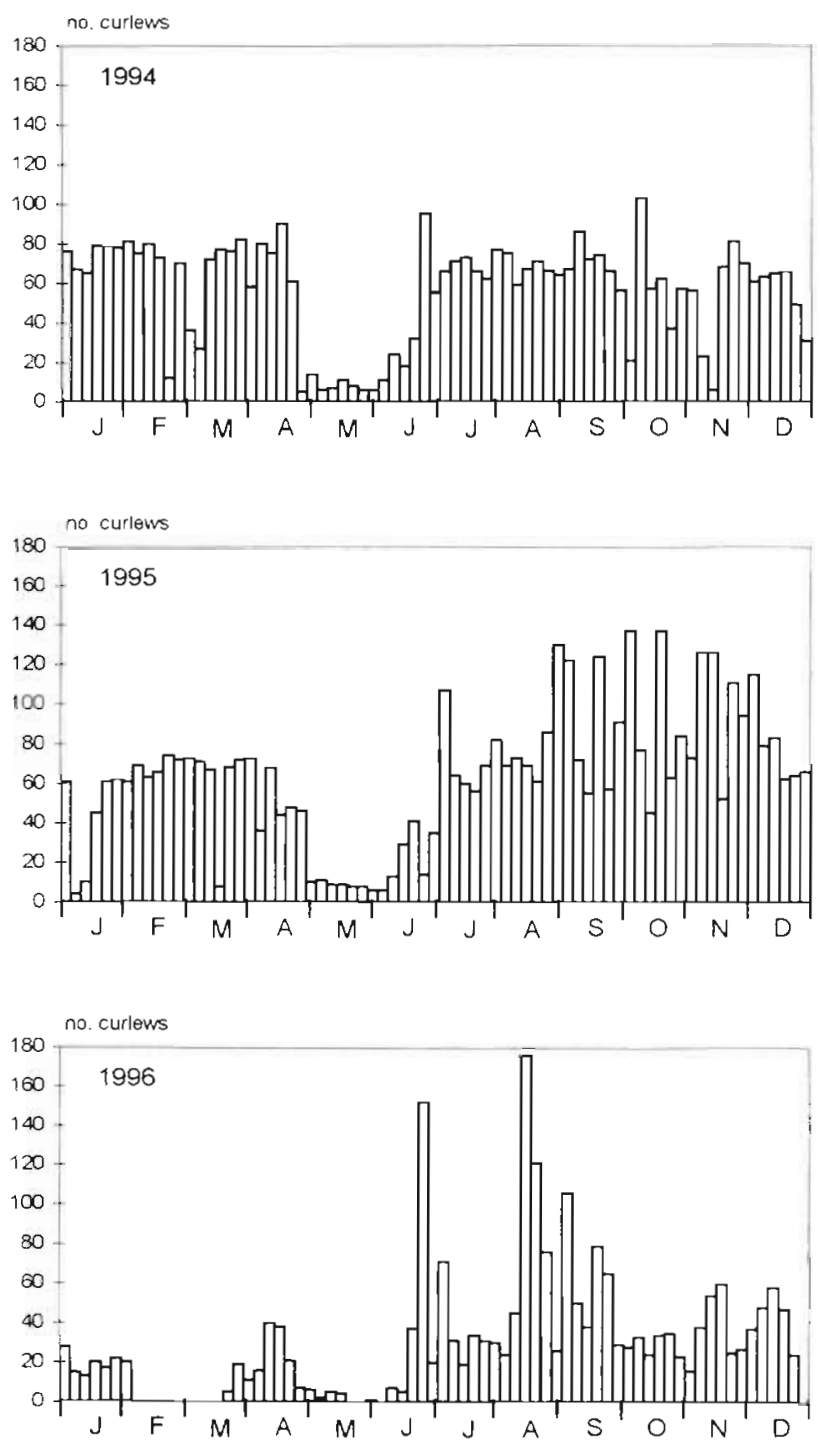

Fig. 2. Numenus arquata. Maximum counts of curlews per $5 \mathrm{~d}$ period at the wind flat area 'Bessinsche Schaar' (Hiddensee) in 1994, 1995 and 1996 
Table 1. Abundance and biomass of potential prey species of curlew in a wind flat area at Hiddensee (July to October 1995). The density of Arenicola marina was estimated according to the number of casts visible in $10 \times 10 \mathrm{~m}$ squares

\begin{tabular}{|c|c|c|c|c|c|c|c|c|c|c|c|c|}
\hline & \multicolumn{3}{|c|}{ July } & \multicolumn{3}{|c|}{ August } & \multicolumn{3}{|c|}{ September } & \multicolumn{3}{|c|}{ October } \\
\hline & $\mathrm{n}$ & Mean & $\mathrm{SD}$ & $\mathrm{n}$ & Mean & SD & $n$ & Mean & SD & $\mathrm{n}$ & Mean & SD \\
\hline \multicolumn{13}{|l|}{1995 abundance (ind. $m^{-2}$ ) } \\
\hline Macoma balthica & 26 & 65 & 75 & 9 & 67 & 112 & 10 & 40 & 70 & 26 & 62 & 94 \\
\hline Mya arenaria & 26 & 19 & 40 & 9 & 0 & 0 & 10 & 30 & 48 & 26 & 50 & 81 \\
\hline Cerastoderma lamarcki & 26 & 4 & 20 & 9 & 0 & 0 & 10 & 0 & 0 & 26 & 8 & 27 \\
\hline Nereis diversicolor & 26 & 2812 & 493 & 9 & 4267 & 1001 & 10 & 5710 & 2523 & 26 & 7854 & 1336 \\
\hline Arenicola marina & & & & & & & 45 & 0.03 & 0.04 & & & \\
\hline \multicolumn{13}{|c|}{1995 biomass ( $\mathrm{mg}$ AFDM $\mathrm{ml}^{-2}$ ) } \\
\hline Macoma balthica & 26 & 151 & 565 & 9 & 128 & 266 & 10 & 217 & 557 & 26 & 339 & 808 \\
\hline Mya arenaria & 26 & 612 & 200 & 9 & 0 & 0 & 10 & 85 & 205 & 26 & 672 & 231 \\
\hline Cerastoderma lamarcki & 26 & 67 & 341 & 9 & 0 & 0 & 10 & 0 & 0 & 26 & 8 & 37 \\
\hline Nereis diversicolor & 26 & 6536 & 1840 & 9 & 6621 & 2051 & 10 & 11494 & 3909 & 26 & 10511 & 2736 \\
\hline
\end{tabular}

\section{Macrobenthic invertebrates in the wind flats}

In addition to mudsnails Hydrobia ventrosa and $H$. ulvae (4600 to 38978 ind. $\mathrm{m}^{-2}$ ) and amphipods Corophium volutator ( 775 to 20500 ind. $\mathrm{m}^{-2}$ ), which are unsuitable as a prey for curlews, the most abundant invertebrate species in the wind flats was the burrowliving ragworm Nereis diversicolor (Table 1). The increasing abundance in summer 1995 was mainly caused by reproduction while the number of worms of the largest size classes (>80 segments) remained constantly below 200 ind. $\mathrm{m}^{-2}$. Lugworms Arenicola marina as a second polychaete species occurred in very low densities (Table 1) and were never found in the samples. The 3 bivalve species Macoma balthica, Mya arenaria and Cerastoderma lamarcki were found in low numbers, too (Table 1), and were mainly represented by small individuals (Fig. 3). Compared to the 1995 situation and following the severe winter 1995/96, ragworms occurred at very low densities in

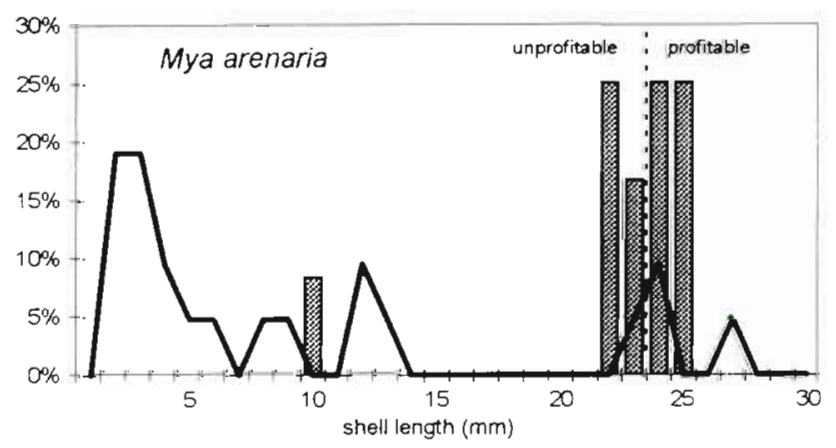

Fig. 3. Mya arenaria. Size distribution of clams in the wind flat area (continuous line, $n=21$ ) and in the diet of curlews (columns, $n=12$ ) at Hiddensee. The broken line indicates the lower size limit of profitable prey according to results from the Wadden Sea (Zwarts \& Wanink 1984) summer 1996 (from May to October averages between 33 and 200 ind. $\mathrm{m}^{-2}$ in 1 of the study plots; Dierschke 1997).

\section{Prey of curlews}

Both field observations and the contents of pellets and droppings revealed the dominance of ragworms in the diet of curlews at about $95 \%$ (ranging from 83.6 to $100 \%$ in the 8 pellets, $90.9 \%$ in total in the 7 droppings), while bivalves contributed about $5 \%$ (Table 2 ). Most of the 72 bivalve hinges found in pellets and droppings could be attributed to Cerastoderma lamarcki $(84 \%)$ with Mya arenaria making up the remaining $16 \%$. No indication of Macoma balthica as content of the diet was found. The scarce polychaete Arenicola marina could not be recorded due to the lack of indigestible body parts, but most likely was taken occasionally.

According to the size of jaws the smallest ragworms taken were in the size classes of 60 to 85 segments (worm length 37 to $79 \mathrm{~mm}$ ), but $82 \%$ belonged to worms of more than 85 segments (Fig, 4). Thus, prey mainly consisted of the numerically very small fraction of large ragworms available in the sediment. The few Mya arenaria consumed also belonged to the largest size classes present in the wind flat area (at most 22 to $25 \mathrm{~mm}$ shell length; Fig. 3). Measuring 10 to $20 \mathrm{~mm}$ (Fig. 5), nearly all Cerastoderma lamarcki eaten by curlews were larger than the only 3 individuals found during sampling of invertebrates (2,5 and $11 \mathrm{~mm})$. The AFDM of the majority of bivalves taken ranged from 49 to $76 \mathrm{mg}$ in $M$. arenaria and from 20 to $95 \mathrm{mg}$ in $C$. lamarcki (September values according to Zwarts 1991), while almost all Nereis diversicolor eaten were above $18 \mathrm{mg}$ AFDM. 


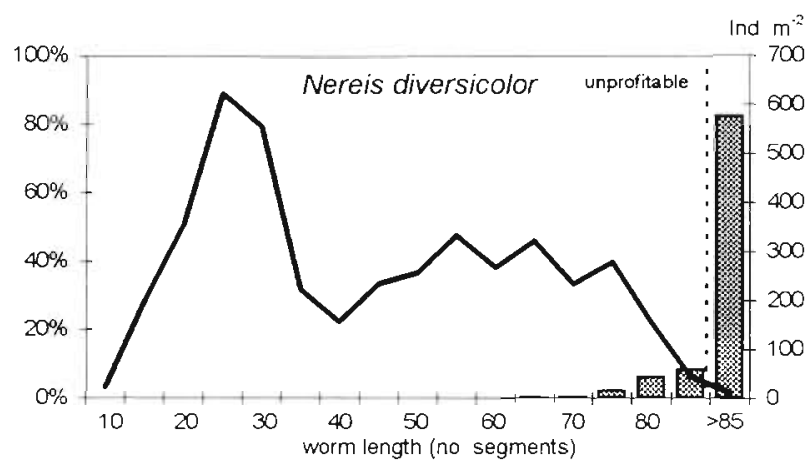

Fig. 4. Nereis diversicolor. Size distribution of ragworms in the wind flat area in August 1995 (continuous line, right axis) and in the diet of curlews (columns, left axis, $n=1355$ ) at Hiddensee. The broken line indicates the lower size limt of profitable prey according to results from the Wadden Sea (Zwarts \& Esselink 1989)

\section{Rate of prey intake}

On average, curlews ingested 3.4 prey items $\mathrm{min}^{-1}$. The slight increase from $3.2 \mathrm{~min}^{-1}$ in July/August (SD $1.4, \mathrm{n}=111$ ) to $3.6 \mathrm{~min}^{-1}$ in September/November ( $\mathrm{SD}$ $1.8, \mathrm{n}=98$ ) was not significant (2-tailed Mann-Whitney $U$-test: $Z=1.32, p=0.186)$. Furthermore, no difference was found between males (mean $3.3 \mathrm{~min}^{-1}$, SD 1.5, $\mathrm{n}=$ 90) and females (mean $3.6 \mathrm{~min}^{-1}, \mathrm{SD} 1.8, \mathrm{n}=92 ; 2$ tailed Mann-Whitney $U$-test: $Z=0.98, p=0.326$ ). However, intake rate differed significantly among the 5 habitats distinguished (Table 3; Kruskal-Wallis-test: $H$ $=15.97, p=0.003)$. This was the result of the difference between exposed and inundated habitats: intake rates in shallow water were $73 \%$ higher $\left(3.5 \mathrm{~min}^{-1}\right)$ than on the exposed wind flats $\left(2.0 \mathrm{~min}^{-1} ; 2\right.$-tailed Mann-Whitney $U$-test: $Z=3.50, \mathrm{p}=0.00047$ ).

Table 2. Percentages of ragworms Nereis diversicolor and bivalves Mya arenaria and Cerastoderma lamarcki in the diet of curlews on the wind flat at Hiddensee. $n$ : number of prey taken during feeding observations and the number of ragworm jaws and bivalve hinges

\begin{tabular}{|lrcc|}
\hline & n & $\begin{array}{c}\text { Ragworms } \\
(\%)\end{array}$ & $\begin{array}{c}\text { Bivalves } \\
(\%)\end{array}$ \\
\hline Pellet no. 1 & 185 & 87.6 & 12.4 \\
Pellet no. 2 & 216 & 91.2 & 8.8 \\
Pellet no. 3 & 280 & 100.0 & - \\
Pellet no. 4 & 125 & 100.0 & - \\
Pellet no. 5 & 392 & 96.2 & 3.8 \\
Pellet no. 6 & 101 & 99.0 & 1.0 \\
Pellet no. 7 & 61 & 83.6 & 16.4 \\
Pellet no. 8 & 23 & 100.0 & - \\
7droppings & 44 & 90.9 & 9.1 \\
All pellets and droppings & 1427 & 95.0 & 5.0 \\
Feeding observations & 1105 & 94.2 & 5.8 \\
\hline
\end{tabular}

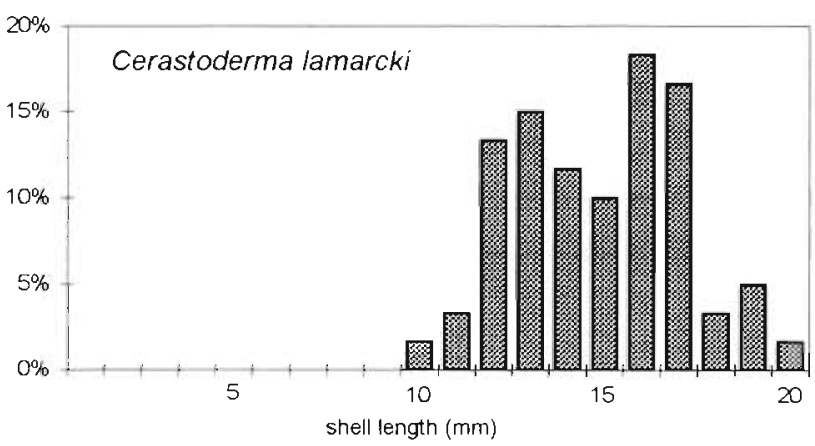

Fig. 5. Cerastoderma lamarcki. Size distribution of cockles in the diet of curlews at Hiddensee $(n=60)$. The only 3 individuals found during sampling measured 2, 5 and $11 \mathrm{~mm}$, respectively

\section{Choice of foraging habitat}

According to 354 scans (with 12232 birds), $84.4 \%$ of curlews foraged in shallow water $(8.8 \%$ in water up to $3 \mathrm{~cm}$ deep, $75.6 \%$ in water 3 to $15 \mathrm{~cm}$ deep), even when most of the flats were exposed (Fig. 6). During the scans, only $0.7 \%$ of curlews were observed on dry wind flats, while $14.9 \%$ used the exposed but wet wind flats (Table 3 ). When not foraging on inundated flats, this happened mostly during falling water levels and on flats exposed very recently (Fig. 6). Within the sampling area, curlews preferred the plots with the deepest water and the furthest distance from the shore (Fig. 1). Densities of foraging curlews were neither related to total abundance and biomass of Nereis diversicolor in the squares (Spearman rank correlation; July/August: abundance $\mathrm{R}_{\mathrm{S}}=-0.20$ and biomass $R_{S}=-0.40$; September/October: abundance $R_{S}=0.42$ and biomass $R_{S}=0.37$, in all $p>0.05$ ) nor to the abundance of ragworms with $>75$ segments (July/August: $\mathrm{R}_{\mathrm{S}}=-0.47$; September/October: $\mathrm{R}_{\mathrm{S}}=0.45$, in both $\mathrm{p}>$

Table 3. Numenius arquata. Intake rates of curlews in different habitats within the Hiddensee wind flat area and the distribution of foraging birds in these habitats (according to 354 scans with 12232 birds)

\begin{tabular}{|c|c|c|c|c|}
\hline & $\underset{n}{\text { Intak }}$ & $\begin{array}{l}\text { rate }(\mathrm{pr} \\
\text { Mean }\end{array}$ & $\mathrm{SD}_{\mathrm{SD}}^{-1}$ ) & $\begin{array}{c}\text { Habitat } \\
\text { choice } \\
(\%)\end{array}$ \\
\hline Dry sand & 8 & 2.01 & 1.83 & 0.7 \\
\hline Wet sand & 7 & 2.00 & 0.81 & 14.9 \\
\hline Shallow water $(1-3 \mathrm{~cm})$ & 34 & 3.10 & 1.42 & 8.8 \\
\hline Shallow water $(3-9 \mathrm{~cm})$ & 82 & 3.37 & 1.55 & 756 \\
\hline Shallow water $(9-15 \mathrm{~cm})$ & 74 & 3.77 & 1.73 & 10.0 \\
\hline
\end{tabular}




\section{Time budgets}

In summer, curlews showed high foraging activity during the first and last hours of daylight, but spent several hours resting during late morning and around noon (Fig 7). This 'siesta' was less pronounced in October and nearly disappeared in winter (Fig. 7). However, total foraging time remained quite constant between 6.8 and $9.3 \mathrm{~h}$ and was much higher only prior to the homeward migration in April (11.6 hi Table 4). Due to the shorter length of the daylight period in winter, the percentage of daylight hours spent foraging was strongly correlated with daylength $\left(R_{S}=\right.$ $-0.836, n=11, p=0.0007$ ). All year round, curlews aggregated to night roosts within the wind flat area in the evening and dispersed again in the early morning (see decreasing foraging activity at dusk in Fig. 7). In contrast to some other shorebird species (oystercatcher Haematopus ostralegus, grey plover Pluvialis squatarola, dunlin Calidris alpina), no curlews

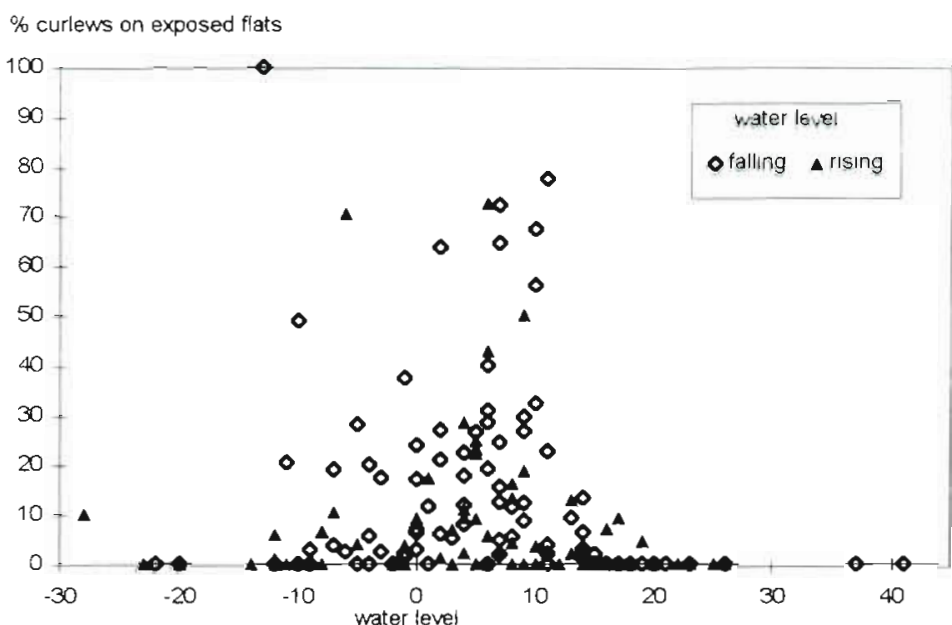

Fig. 6. Numenius arquata. Percentages of foraging curlews on exposed wind flats in relation to water level $(0$ : mean sea level) and its change

(90 scans during falling and 76 scans during rising water level)

were seen to forage on the Hiddensee wind flat during nocturnal observations at full moon in August 1994 and 1995

Table 4. Numenius arquata. Total time and percentage of daylight period spent foraging by curlews on the Hiddensee wind flat In addition, the daylength ( $45 \mathrm{~min}$ before sunrise until $45 \mathrm{~min}$ after sunset) is given for the median date of each period

\begin{tabular}{|c|c|c|c|c|c|c|}
\hline \multirow{2}{*}{$\begin{array}{l}\text { Period } \\
\text { 3-18 Jul } 1994\end{array}$} & \multirow{2}{*}{$\begin{array}{c}\text { n scans } \\
42\end{array}$} & \multirow{2}{*}{$\begin{array}{l}n \text { birds } \\
2360\end{array}$} & \multicolumn{2}{|c|}{ Daylength (min) } & \multirow{2}{*}{$\begin{array}{c}\text { Total foraging } \\
\text { time (min) } \\
503\end{array}$} & \multirow{2}{*}{$\begin{array}{c}\% \text { daylight } \\
\text { foraging } \\
45.8\end{array}$} \\
\hline & & & $10 \mathrm{JuJ:}$ & 1082 & & \\
\hline 4-15 Aug 1993 & 62 & 3390 & 9 Aug: & 1006 & 518 & 51.5 \\
\hline 1-18 Aug 1995 & 103 & 5835 & 10 Aug: & 1003 & 471 & 47.0 \\
\hline $1-21$ Sep 1993-95 & 68 & 4339 & 11 Sep: & 871 & 521 & 59.8 \\
\hline $2-9 \operatorname{Oct} 1995$ & 70 & 4179 & 5 Oct: & 783 & 494 & 63.1 \\
\hline 30 Oct-13 Nov 1995 & 81 & 5575 & 6 Nov: & 639 & 474 & 74.2 \\
\hline $18-30$ Nov 1994 & 43 & 2660 & 24 Nov: & 577 & 4.09 & 70.9 \\
\hline 30 Nov-11 Dec 1995 & 81 & 5395 & 6 Dec: & 549 & 468 & 85.2 \\
\hline 21 Jan-2 Feb 1995 & 45 & 2148 & 27 Jan: & 605 & 530 & 87.6 \\
\hline 1-13 Mar 1995 & 83 & 5039 & 7 Mar: & 762 & 558 & 73.2 \\
\hline 21-30 Apr 1995 & 60 & 1572 & 25 Apr: & 971 & 694 & 71.5 \\
\hline
\end{tabular}

Table 5. Numenius arquata. Long-term average numbers of curlew during the didy and in the evening (night roost) on different wind flats on the German Baltic Sea coast in August to October. The density is given as the numbers during the day in relation to the maximum extension of the wind flats during low water level

\begin{tabular}{|lrcccl|}
\hline & Area (ha) & Day & Evening & $\begin{array}{c}\text { Daytime density } \\
\text { (birds ha }{ }^{-1} \text { ) }\end{array}$ & Source \\
\hline Oehe-Schleimünde & 140 & $20-40$ & $?$ & $0.14-0.29$ & Erfurt \& Dierschke (1992) \\
Wismar Bight & 200 & $40-60$ & $800-1500$ & $0.20-0.30$ & Freitag (1987), J. Kube (pers. comm.) \\
Bock & 1500 & $200-250$ & $250-300$ & $0.13-0.17$ & Graumann et al. (1980). Kube \& Struwe (1994) \\
Vierendehlgrund & 1500 & $100-200$ & $?$ & $0.06-0.13$ & Vogelwarte Hiddensee (unpubl.) \\
Bessinsche Schaar & 180 & $60-80$ & $80-120$ & $0.33-0.44$ & This study \\
Peenemünder Haken & 200 & $30-80$ & $?$ & $0.15-0.40$ & B. Schumeister (pers. comm.) \\
Struck & 50 & $5-10$ & $?$ & $0.10-0.20$ & D. Sellin (pers. Comm.) \\
\hline
\end{tabular}




\section{DISCUSSION}

In autumn, the average of 227000 curlews present in $4500 \mathrm{~km}^{2}$ of mudflat in the Wadden Sea (Meltofte et al. 1994) results in a density of 0.5 birds ha ${ }^{1}$, although many parts of the area hold more than 1 bird ha ${ }^{-1}$ In contrast, much lower densities are observed on wind flats along the German Baltic Sea coast (at most 0.1 to 0.3 birds ha ${ }^{-1}$; Table 5). However, in the study area at Hiddensee densities were only slightly lower than the overall abundance in the Wadden Sea ( 0.33 to 0.44 birds ha $^{-1}$; Table 5 ), and the effective density was even higher, as $84 \%$ of the foraging curlews used only stretches of shallow water. This choice of habitat is explained by the rate of prey intake which is twice as high in shallow water as compared to exposed flats. While no ragworms could be observed on the exposed wind flats, the high intake rate in shallow water is made possible by a high surface activity of ragworms, leading to improved detectability for predators (Dierschke 1997). Furthermore, in addition to other feeding mechanisms such as deposit feeding, ragworms as the main prey organism of curlews are known to filter feed in inundated habitats (Goerke 1971). This actıvity might enable curlews to detect ragworms due to air bubbles and water streams (Zwarts \& Esselink 1989) and makes capture easier because worms are closer to the surface.

Within the wind flats, curlews not only preferred the most suitable habitat, but also took the most favourable prey In contrast to the Wadden Sea (Zwarts \& Wanink 1984, Zwarts \& Esselink 1989). the Hiddensee wind flat contained only few prey organisms which are profitable with regard to the relation of costs and benefits. Our prey analyses showed that curlews are able to find the scarce ind1viduals of Nereis diversicolor and Mya arenaria that are known to be profitable from studies in the Wadden Sea (Zwarts \& Wanink 1984, Zwarts \& Esselink 1989). Therefore, curlews are more skiltul than ourselves as benthic ecologists, as we found only a few of these large individuals during our random sampling. The core sampling method may fail to estimate the abundance of invertebrates occurring at very
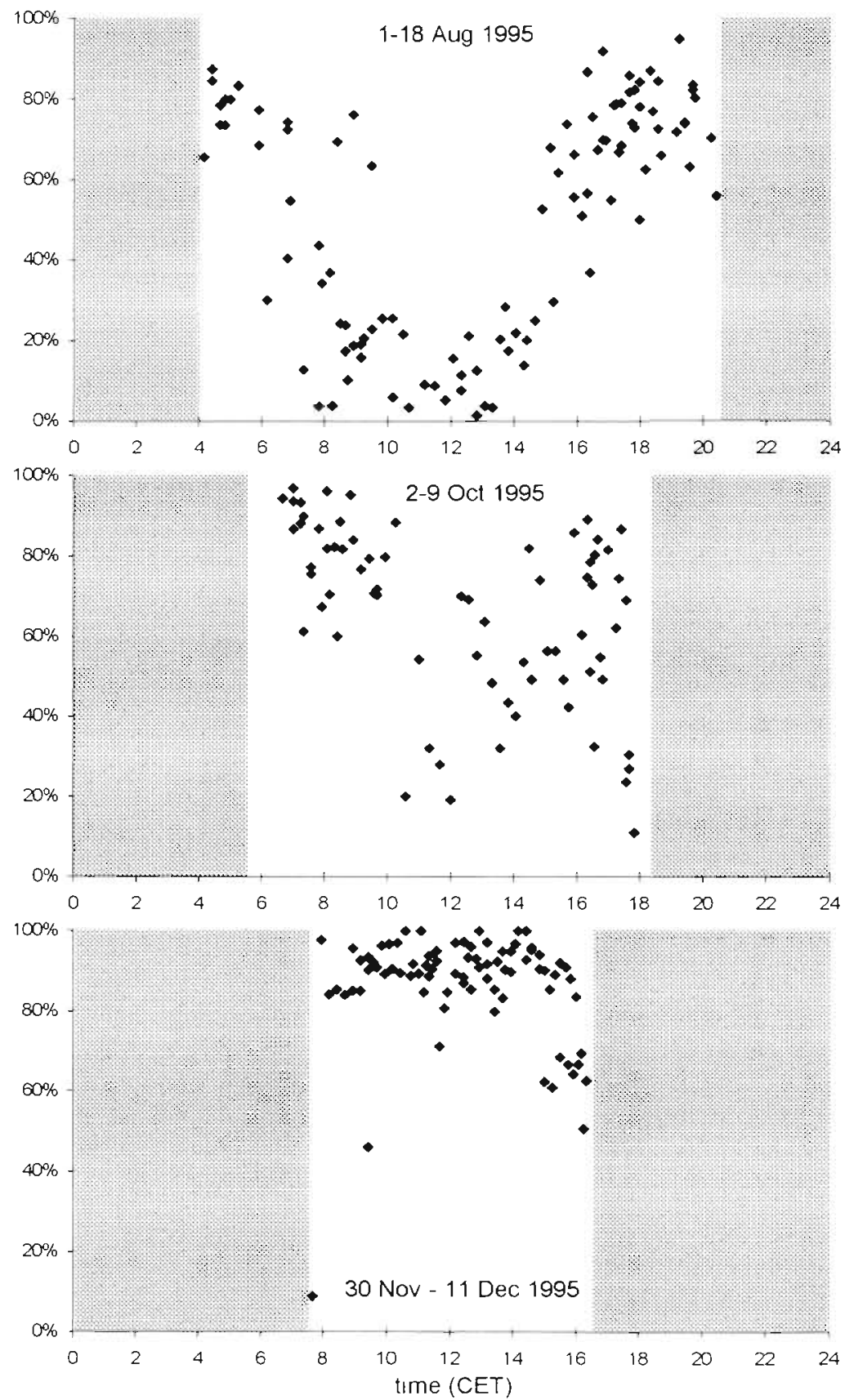

Fig. 7. Percentages of foragıng burds among curlews present on the Hiddensee wind flat in August (103 scans). October (70 scans) and December (81 scans) Results of all scans are shown for the daylight period $(45 \mathrm{~min}$ before sunrise until $45 \mathrm{~min}$ after sunset, penods of darkness are shaded) For additional information see Table 4

low density (cf. Powllleit et al. 1995 for Cerastoderma). Furthermore, in a nearby habitat, burrows of $N$. diversicolor were found to be up to $25 \mathrm{~cm}$ deep (Zettler et al. 1994), thus slightly exceeding the maximum depth of our corer.

In addition to this highly selective and effective feeding strategy, prolonged phases of restıng indicated that 
curlews needed only a few hours of foraging during daylight to maintain their energy balance. Probably they do not even feed at night, since they aggregated to night roosts in the same way as described from other staging and stopover sites (Gloe 1972, Freitag 1987). Compared to smaller shorebird species, curlews spend only a small fraction of daylight hours or tidal cycles for foraging, even in tidal wetlands (Goss-Custard et al. 1977. Pienkowski 1981, Hötker 1995), but in addition may show nocturnal activity (Hötker 1995). However, nocturnal foraging is not necessary for curlews at Hiddensee as is indicated by a rough estimate of daily energy intake from July to October. Taking into account the intake of the smallest profitable ragworms (20 mg AFDM; with an energetic content of $23.79 \mathrm{~kJ}$ $\mathrm{g}^{-1}$ AFDM; Bast \& von Oertzen 1976) at a rate of $3.5 \mathrm{~min}^{-1}$, curlews ingest 1649 to 1824 prey and 784 to $868 \mathrm{~kJ}$ during their daily foraging time of 471 to 521 min (Table 4). Even this consideration of only relatively small prey results in a gross intake comparable to 2.1 to 2.3 times the estimated basal metabolic rate $(B M R)$ for a shorebird weighing $800 \mathrm{~g}\left(372 \mathrm{~kJ} \mathrm{~d}^{-1}\right.$ according to Kersten \& Piersma 1987). However, as many prey items were larger, the estimated daily energy expenditure of about 3 times BMR (Kersten \& Piersma 1987) can be assumed to be met.

Thus, in contrast to Kube's (1994) suggestion, the studied wind flat area at Hiddensee does not seem to be an unfavourable feeding habitat for curlews. Compared to tidal wetlands, they are available almost continuously. Curlews usually cease foraging at water levels of more than $30 \mathrm{~cm}$ above mean sea level, a relatively rare event (only on $12 \mathrm{~d}$ during the study period from July to November 1995). Even the unpredictability of water level fluctuations is less important for curlews, as they have access to water up to $15 \mathrm{~cm}$ deep due to their relatively long legs. Therefore, they are more flexible in habitat choice than other shorebird species. If they are forced to leave the study site, curlews have the possibility to switch to other wind flats nearby (with a different vertical situation compared to mean sea level) or to fields and meadows on the adjacent islands. However, the quite high curlew densities compared to other Baltic Sea wind flats (Table 5) may indicate unusually favourable conditions at Hiddensee. In contrast to at least some of the sites mentioned in Table 5, the studied wind flat area is relatively steep, situated deep in relation to mean water level and open to water bodies on 3 sides. This enables emigration and immigration processes which are the leading force in the establishment of benthic invertebrates at wind flats (Kube 1992). For the same reason, the bivalves Mya arenaria and Cerastoderma lamarcki occur at Hiddensee in contrast to other Baltic coastal sites (J. Kube pers. comm.).
The advantages of wind flats mentioned above are counterbalanced by the dependence more or less on 1 prey species. Long periods of low water levels leading to dried flats as well as periods of temperatures below $0.5^{\circ} \mathrm{C}$ combined with low salinity can induce mortality in populations of Nereis diversicolor (Hohendorf 1963, Arndt 1988, Kube 1992). After the Hiddensee wind flat was covered with ice for 4 mo in winter 1995/96, the abundance of ragworms was only 33 to $200 \mathrm{ind} . \mathrm{m}^{-2}$ in summer 1996 (Dierschke 1997). As a possible result the number of curlews was also lower in 1996 than in the years before (30 to 40 birds; Fig. 2). However, even in this much more extreme situation curlews were able to find the few ragworms present (pers. obs.). Therefore, the reduced abundance of prey seems to be outweighed by the constant availability of suitable foraging habitats. As on the tidal flats of northwest European estuaries, curlews experience predictable prey availability on a day-to-day basis on the wind flats, where the almost continuous availability of shallow water habitats instead of the intermittent exposure produced by tides is characteristic. Consequently, foraging activity follows a diurnal instead of a tidal rhythm. Feeding is always possible in daylight, which can be regarded as advantageous for visual location of prey in shallow water. In conclusion it must be stressed that the wind flats at Hiddensee can hold certain numbers of curlews which almost exclusively use this habitat for feeding. Population size seems to be determined by the food supply, which is controlled by meteorological conditions (wind and winter temperature, see above).

Acknowledgements. For help during field work we are grateful to O. Aust, H. Haag, A. J. Helbig, G.-H. Kraus and C. Wegst. J. Kube and H.-O. von Walter kindly supplied sampling equipment while $M$. Köster made available facilities at the Institut für Ökologie (Hiddensee). For discussions and improvements of the manuscript we are indebted to A. J. Helbig, J. Kube, K. Reise and 3 anonymous referees.

\section{LITERATURE CITED}

Altmann J (1974) Observational study of behavior: sampling methods. Behaviour 49:227-267

Arndt EA (1988) Zusammenfassende Ergebnisse von Untersuchungen am Makrozoobenthos der Darß-Zingster Boddenkette von 1969-1987 Wiss Z Wilhelm-Pieck-Univ Rostock, Naturwiss Reihe 37:6-12

Bast HD, von Oertzen JA (1976) Zusammenstellung von Energieäquivalenten aquatischer Organismen unter besonderer Berücksichtigung der Ostsee. Teil II. Wiss Z Univ Rostock, Math-Naturwiss Reihe 25:295-304

Beukema JJ, Essink K, Michaelis H, Zwarts L (1993) Year-toyear variability in the biomass of macrobenthic animals on tidal flats of the Wadden Sea: how predictable is this food source for birds? Neth J Sea Res 31:319-330

Brosin HJ (1965) Hydrographie und Wasserhaushalt der Boddenkette südlich des Darß und des Zingst. Veröff Geophys Inst Univ Leipzig 18:277-381 
Dekinga A, Piersma T (1993) Reconstructing diet composition on the basis of faeces in a mollusc-eating wader, the knot Calidris canutus. Bird Study 40:144-156

Dierschke V (1997) Unterschiedliches Zugverhalten alter und junger Alpenstrandläufer Calidris alpina: ökologische Untersuchungen an Rastplätzen der Ostsee, des Wattenmeeres und auf Helgoland. Cuvillier Verlag, Göttingen

Erfurt HJ, Dierschke V (1992) Oehe-Schleimünde-Naturschutzgebiet an der Ostseeküste Schleswig-Holsteins. Seevögel Sonderh 13:1-104

Esselink P, Zwarts L (1989) Seasonal trend in burrow depth and tidal variation in feeding activity of Nereis diversicolor. Mar Ecol Prog Ser 56:243-254

Freitag B (1987) Zum Schlafplatzflug des Großen Brachvogels (Numenius arquata) in der Wismar-Bucht. Ornithol Rundbr Mecklenburgs NF 30:25-26

Gloe P (1972) Vom Schlafplatzflug des Großen Brachvogels, Numenius arquata, an der Meldorfer Bucht. Corax 4:56-60

Goerke H (1971) Die Ernährungsweise der Nereis-Arten (Polychaeta, Nereidae) der deutschen Küsten. Veröf Inst Meeresforsch Bremerhaven 13:1-50

Goss-Custard JD, Jenyon RA, Jones RE, Newbery PE, Williams RleB (1977) The ecology of the Wash. II. Seasonal variation in the feeding conditions of wading birds (Charadrii). J Appl Ecol 14:701-719

Graumann G, Jäkel D, Müller S, Zöllick H (1980) Die Vögel des NSG Bock und Hohe Düne von Pramort. Natur Natursch Mecklenburg 16:5-79

Hohendorf K (1963) Der Einfluß der Temperatur auf die Salzgehaltstoleranz und Osmoregulation von Nereis diversicolor O.F. MUELL. Kieler Meeresforsch, Sonderh 19:196-218

Hötker H (1995) Aktivitätsrhythmus von Brandgänsen (Tadorna tadorna) und Watvögeln (Charadrii) an der Nordseeküste. J Ornithol 136:105-126

Kersten M, Piersma T (1987) High levels of energy expenditure in shorebirds; metabolic adaptations to an energetically expensive way of life. Ardea 75:175-187

Kube J (1992) Das Makrozoobenthos des Windwatts am Bock - Szenario des Jahres 1991 Thesis, Univ Rostock.

Kube J (1994) Aspekte der Nahrungsökologie ziehender Limikolen an der südlichen Ostseeküste. Corax 15, Sonderh 2:57-72

Editorial responsibility: Otto Kinne (Editor),

Oldendorf/Luhe, Germany
Kube J, Struwe B (1994) Die Ergebnisse der Limikolenzählungen an der südwestlichen Ostseeküste 1991. Corax 15, Sonderheft 2:4-56

Meltofte H, Blew J, Frikke J, Rösner HU, Smit CJ (1994) Numbers and distribution of waterbirds in the Wadden Sea. Wader Study Group Bull 74:1-192

Pienkowski MW (1981) Differences in habitat requirements and distribution patterns of plovers and sandpipers as investigated by studies of feeding behaviour Verh Ornithol Ges Bayern 23:105-124

Powilleit M, Kube J, Maslowski J, Warzocha J (1995) Distribution of macrobenthic invertebrates in the Pomeranian Bay (Southern Baltic Sea) in 1993/94. Bull Sea Fish Inst Gdynia-Poland 3:75-87

Remane A (1940) Einführung in die zoologische Ökologie der Nord- und Ostsee. In: Grimpe G (ed) Die Tierwelt der Nord- und Ostsee, Vol 1a. Akademische Verlagsgesellschaft, Leipzig, p 1-238

Vader WJM (1964) A preliminary investigation into the reactions of the infauna of the tidal flats to tidal fluctuations in water level. Neth J Sea Res 2:189-222

Zettler ML, Bochert R, Bick A. (1994) Röhrenbau und Vertikalverteilung von Marenzelleria viridis (Polychaeta: Spionidae) in einem inneren Küstengewässer der südlichen Ostsee. Rostocker Meeresbiol Beitr 2:215-225

Zwarts L (1991) Seasonal variation in body weight of the bivalves Macoma balthica, Scrobicularia plana, Mya arenaria and Cerastoderma edule in the Dutch Wadden Sea. Neth J Sea Res 28:231-245

Zwarts L, Esselink P (1989) Versatility of male curlews Numenius arquata preying upon Nereis diversicolor: deploying contrasting capture modes dependent on prey availability. Mar Ecol Prog Ser 56:255-269

Zwarts L, Wanink J (1984) How oystercatchers and curlews successively deplete clams. In: Evans PR, GossCustard JD, Hale WG (eds) Coastal waders and wildfowl in winter. Cambridge University Press, Cambridge, p 69-83

Zwarts L, Wanink JH (1993) How the food supply harvestable by waders in the Wadden Sea depends on the variation in energy density, body weight, biomass, burying depth and behaviour of tidal-flat invertebrates. Neth $J$ Sea Res 31 $441-476$

Submitted: May 29, 1997; Accepted: September 29, 1997 Proofs received from author(s): November 17, 1997 